\title{
Governing Vitalities and the Security State
}

\section{Governing Vitalities}

In the lectures on Security, Territory, Population, his account of the consolidation of what he called the Security State, Michel Foucault emphasized the ways that a new articulation of biopolitics and governmentality altered the relations between population and territory (Foucault, 2007; Elden, 2007; Legg, 2005; 2011; Nally, 2011). ${ }^{1}$ Indeed, for Foucault these new relations were in part constitutive of modern notions of state and people, such that, and again in part, a state effect is something produced by the strategies of biopolitics and governmentality. As always with Foucault, a historical argument was made for a political purpose. In order to attend to something contingent in the present, Foucault characteristically illustrated the conditions of its emergence, an intellectual strategy described by Mitchell-Dean as making critical and effective histories (Dean, 1994; Kearns, 2007). In broad terms, Foucault highlighted a shift from territory to population, from sovereignty to security, as a focus for the arts of government. For Foucault, the monarch's concern with sovereignty in the earlier period, variously located as ending some time between the mid-seventeenth and late-eighteenth centuries, emphasized the regulation of territorial boundaries. In the security state that followed, the imperatives of economic circulation breached the walls of sovereignty and the arts of government now attended more to the capacities of the state, regulating population and other resources. The political issue that arises from this, exemplified for Foucault in various ways by

\footnotetext{
${ }^{1}$ I want to thank Chris Philo both for the title and for the provocation of an invitation to contribute to the plenary sessions on "Geographies of Insecurity" at the RGS/IBG Conference in Edinburgh, July 2012.
} 
Sweden and Germany, was about regulating individuals to give collective security against threats to the productivity, or force, of the body politic.

In this essay, I want to take up the geographical and vital themes of this set of lectures and assess both the nature of the break posited by Foucault and the political purchase afforded by this view of the distinctiveness of the present. My strategy is to reverse Foucault's emphasis and look for aspects of the regulation of life in the earlier period and to aspects of the regulation of territory in the later one. This is not because I think Foucault ignores vitality in his first period or ignores territoriality in his second, but, rather, that the integration of the two themes, rather than the predominance of one over the other, shows the importance in both periods of a set of relations about which Foucault has rather little to say altogether. My conclusion is that, in both periods, life and space are woven together in ways that are distinctly geopolitical and, furthermore, that this dimension of the spatiality of vital security gives us important purchase upon our moment of present danger. Although Foucault saw the Socialist focus upon the state as obscuring the nature of government, his own treatment of the arts of government took states as objects in isolation, and indeed very often took France as paradigm, thus occluding the significance of geopolitics and geography. Yet without this international dimension, the modern appeal to security is but poorly understood, and the over-determining relations between capital and imperialism practically invisible.

I address Foucault's analysis by asking, first, how vitality was taken up as an issue by government in the period of sovereignty, the period before Foucault finds population to be a focus of the state. A qualified right to life was emergent in the government responsibilities of the modern states system. Although intended primarily to counter threats to public disorder (Walter and Schofield, 1989) and later to secure 
the manpower necessary for a strong economy and an effective army (Boyle, 2006; Elbe, 2006), the reasons of state included the securing of life against the threat of famine or epidemic. These relations of vitality with security although somewhat obvious have not received the geographical attention that they deserve (Kearns and Reid-Henry, 2009). These concerns animated spatial practices that are at the heart of the geopolitics of the states system, as may be illustrated from the famine and epidemic practices of early modern European states.

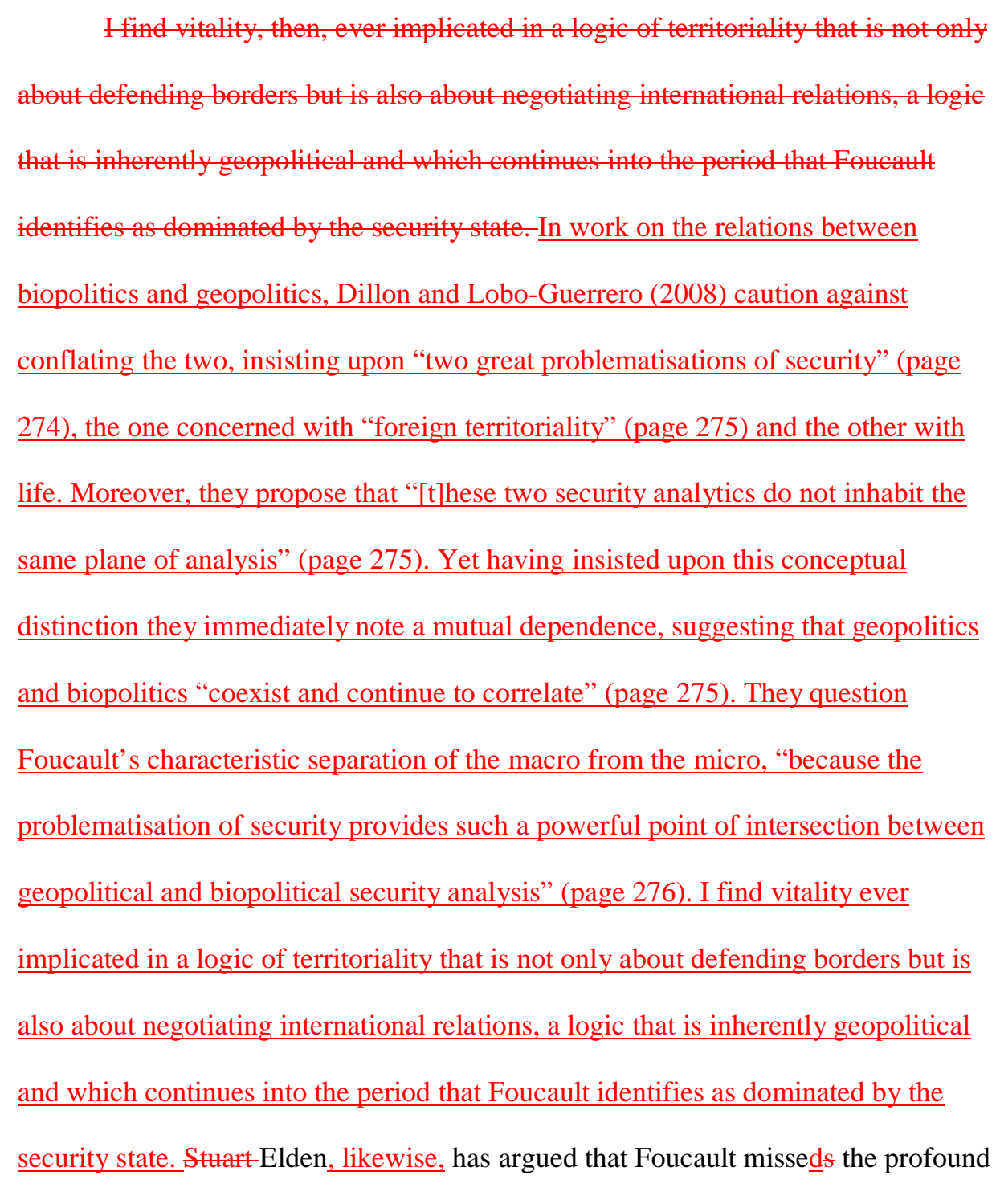


territoriality of the arts of government in this laterfor this later period, ${ }_{2}-$-following the Treaty of Westphalia (1648). My argument is similar but, whereas Elden looks at the cartographic concern with the qualities of territory as a sort of estate, I am interested in the related issue of the territoriality of geopolitical relations, elided by Foucault for both the period of sovereignty and the period of the security state. This brings me to an evaluation of the political purchase of Foucault's notion of the security state where, again, I note an important and neglected geopolitical dimension to the regulation of life. As Brown (2011) notes, international concern with public health is most readily prompted when the health of the rich is endangered by the diseases that the poor do not keep to themselves. But, more than this, the idea of global as opposed to international health is very often " "transnational” from a US base and working with and for US interests' (Bashford, 2006, page 72). Rather than producing a new security state, the latest reconfiguration of security and vitality may promise a revivified imperial geopolitics.

\section{Vitality and Security}

In early modern Europe, when food was short, monarchs and town corporations anticipated social unrest; and often got it (Tilly, 1983). Food markets were regulated by notions of moral economy (Thompson, 1971). Elaborate English regulations about the regulation of the food market date from at least 1266 with an Assize of Bread and Ale. ${ }^{2}$ Bread was sold in loaves of specified quality at a fixed price, for example a cheap loaf of inferior grain sold for a farthing and was known as a small cocket loaf. The assize (or group of magistrates sitting to make regulations) fixed the weight of

\footnotetext{
${ }^{2} 1$ Statutes of the Realm 199-200 (1235-1377) Statutes of Uncertain Date. This statute was collected (1811) in the critical and official edition of the Statutes of the Realm and given as of uncertain date. It has often been assigned to the 51st year of the reign of Henry III (1266-7). I quote from the version published in 1811.
} 
the bread according to the price of wheat; when prices were high, loaves were small. For minor offences, bakers were fined but for seriously skimping on the size of the low-grade loaves they were to "suffer the Judgment of the Body, that is to say, the Pillory.” Other measures in city charters allowed magistrates to regulate markets to prevent merchants cornering supply. It was illegal to force up food prices by: buying up grain before it reached open market (forestalling), acquiring an excessive share of the produce (engrossing), or repurchasing a large market share before wholesale became retail (regrating). These have been described as "the earliest attempts in English Law to regulate trade” (Herbruck, 1929, page 365).

Grain supply would fluctuate with the harvest and in bad years the poor might find their loaves but one half the size of more bountiful times. Again, both city and national government intervened to protect the poor from the full force of nature. From 1411 the Corporation of the City of London used Leadenhall as a public granary to hold grain from good years to the leaner that may follow and from "[a]t least as early as 1390 London tried the plan of meeting a dearth by the municipal purchase of corn” (Gras, 1915, page 79). From 1597, the English government assumed the right to demand that in hungry years magistrates should be bound by a so-called Book of Orders that instructed them to seek out private stocks of grain and force delivery to local markets (Nielsen, 1997).

In other words, food, which probably absorbed about half the income of the English labourer in the early modern period (Shammas, 1983), was a commodity that was heavily regulated. Food security was a matter of government policy, both local and national. Faced with the market, isolated individuals would not get food at a fair price. Harvest fluctuations and market manipulation held lives to ransom and individuals required protecting. The state needed to act because individuals were 
unable to defend themselves and, in effect, states created a "social shell" for their subjects (Kearns, 2006a).

Similar issues arise with the collective action taken against epidemic disease. Plague regulations addressed with cordons sanitaires and quarantine, the threat from without (perceived in intercourse with foreign parts), and addressed with isolation and sanitation, the threat from within (mnderstood as proceedingthought to proceed from disorderly or unregenerate persons and places). As PaulSlack (1988, page 433) remarks, "[a]ll this necessitated the growth of local administrative machines and an expansion of state power.” Thus at Milan in 1374, the regulations instructed the priests, “under pain of being burnt alive” to visit the sick and determine if there was plague, and it was further ordered that "each person who displays a swelling or tumour shall immediately leave the city, castle or town where he is and take to the open country [...] until he either dies or recovers” (Horrox, 1994, page 203). In October 1579, the city of Seville responded with alarm to reports of plague in Lisbon since the immediate result was that folk from the infected city were fleeing to apparent safety in Seville (Cook and Cook, 2009). A plague commission was appointed and it adopted what by the sixteenth century were the more or less standard responses in southern Europe. It sent commissioners to the suspect districts (initially to Portugal and later to the countryside immediately around Seville) and it prevented traders from entering the city from places about which the city had received worrying report.

The Italian regulations were the earliest and became the most elaborate in Europe and when, in 1578, the English government feared the imminent arrival of plague, the Privy Council instructed the City of London to consider adopting a version of the regulations used by Milan during the severe outbreak of 1576-7 and it 
forwarded to the Lord Mayor copies of the forms and orders issued by Milan (Basing and Rhodes, 1997). In matters of plague policy London was some two centuries behind the innovations of the Italian cities of the mid fourteenth century. Even when it did adopt the measures of quarantine, its practice within London became itself a risk to public order because being visited upon the poor more often than upon the rich, it was felt as a piece of class-biased legislation (Newman, 2012). Nevertheless, London did take up the challenge of isolating the sick from the well and of ensuring that there were officials to administer the policy. The Orders of 1665 instructed, among other things, that each parish should have a number of Examiners who would visit the denizens of the sick and "command restraint of access, until it appear what the disease shall prove" and as incentive to take up this duty, they were warned that "if any fit Person so appointed, shall refuse to undertake the same, the said parties so refusing, to be committed to Prison until they shall conform themselves accordingly" (Anon, 1665, n.p.).

Again, we see that a social shell is arranged around the individual. Individuals could not secure these arrangements for themselves, however wealthy they might be. It required government to interrupt commerce, to prohibit the chaotic mixing of the sick with the well, and to force officials to remain and administer the epidemic crisis despite their self-interest in flight.

\section{Security, Territory, Population}

These epidemic and famine measures were central to Michel-Foucault's account of the development of biopower and in the lectures of 1978 on Security, Territory, Population (Foucault, 2007; Nally, 2011), he set out an account of the spatial strategies of the management of famine and disease under three different although overlapping regimes of sovereignty, discipline, and governmentality. Sovereignty 
understood space as realm or royal estate and treated the protection of state borders as the way to ensure the safety of the monarch's rule. This regime managed individuals through juridical proscriptions, banning certain acts. Broadly speaking, Foucault saw the sovereign state as characteristic of the feudal period up to about the mid sixteenth century. Discipline, rather, conceptualized space as divisible into cells that could be regulated. Under discipline, people were imagined as a multiplicity of individuals who can each be trained to conform to an ideal (the norm as prescription). Foucault argued that the dissolution of feudalism, saw the emergence of a new territorial state with an administrative monarchy implementing disciplinary measures, and he suggested that this regime characterized Europe in the period from the mid-sixteenth to the later part of the eighteenth century. Finally, Foucault wrote about the emergence of state governmentality from the late eighteenth century. This regime projected space as a zone of circulation and as an environment or milieu. It understood individuals as self-reflexive subjects who might be induced to monitor their own conduct in line with the average (the norm as mean) and in this way enact the pursuit of those natural desires which, unfettered, conduce to the greatest social good. It also projected the population as an aggregate that could be regulated in its fertility and mortality, health and wealth, by state interventions to set the context in which individuals made decisions about work, family, and savings.

With regard to famine, the primary distinction Foucault made was between the sovereign and administrative states on one hand and the commercial state of circulation on the other. While the first two policed borders rigorously, the last encouraged the free movement of commodities. For epidemics, again Foucault distinguished between constraints of the sovereign and administrative states and the permissions of the commercial state. Under the commercial state, the government 
regulated population dynamics with poor law, tax, education, and other policies. But it also treated the urban environment as an object of intervention and to clean away the stagnant ordure that was thought to create miasmas and thus disease, it provided building codes, publicly owned water and sanitation, and controls on overcrowding in lodging houses. In a way, Foucault presented this focus on population and milieu as a new materialism that put into the shade, even if it did not entirely displace, the earlier strategies of territorial regulation.

These are useful notes towards a study of the spatialities of European state strategies in the fields of famine and disease and the distinctions to which Foucault attended are suggestive. Foucault described the shift to governmentality, with its focus on population and milieu, as a shift towards an apparatus of security. Yet, we need to consider whether characterizing security in terms of biopolitics and governmentality adequately captures the distinctiveness of the modern challenge but before I approach this political question, I want first to examine a little further the historical account given by Foucault. I want first to say a bit more about vitality and the arts of government in the period before governmentality, in the period for which Foucault used the language of safety rather than of security. For this early period there is no equivalent to the full-blown materialism of, say, Malthusian population policies and in this sense, Foucault gives us purchase on an important innovation when he identifies "population" as a new object of detailed policy intervention from, say, the mid-eighteenth century (Legg, 2005). But this is a matter of degree and not kind which is important because the elements of population and security we find in the earlier period were at that time articulated with the strategies of territoriality and sovereignty that Foucault sees being eclipsed by more fully developed population policies. The compatibility of population and territory raises different political, and I 
would say geopolitical, questions than highlighted in Foucault's treatment of the Security State.

My second set of historical remarks concern Foucault's treatment of geography and geopolitics. In an analysis of the way governmentality and biopolitics became thinkable and practicable, Foucault treats the state as the central agent, yet

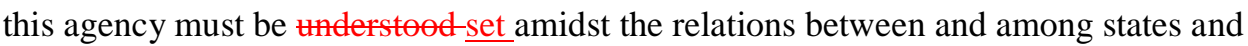
empires. Diplomatic and military aspects of the health and famine strategies are shaded by the focus on states in isolation. There was something of a distributed agency (Quack, 2007) in the elaboration of regulations that involve inter-state conversations, implicit or explicit. The significance of geopolitics raises issues that I will examine in a concluding discussion of the AIDS pandemic and current biopolitical security.

\section{Vitality and the Arts of Government}

Foucault argued that states prioritized the safety of monarchical rule in the medieval and early-modern periods but that from the late-eighteenth century, this was supplemented and then overshadowed by a concern with security, delivered through related techniques of governmentality and biopolitics. There are some difficulties with this analysis from the perspectives both of vitality and security. Even though the aggregate and statistical analyses that Foucault highlighted as part of the materialism of governmentality were elaborated more fully in the nineteenth century, the question of vitality was not really absent from the early territorial or disciplinary famine and epidemic strategies. For example, Florence had Bills of Mortality from 1385 (Cipolla, 1978). These records were generated from the weekly reports made by the city's gravediggers to, respectively, the Grascia, a body charged with securing the provisioning of the city, the Guild of Physicians and Apothecaries who paid the 
gravediggers, and, from 1607, also to the Health Magistracy of Florence who demanded that the gravediggers report "in writing all those who die in this city during the week, with specific reference to the quarters and the places where they die and the ailments they heard had caused the deaths” (Cipolla, 1978, page 454).

The weekly publication of Bills of Mortality acted as a sort of morbid barometer warning residents when summers were turning so sickly that if means allowed they should consider country residence, and alerting the Health Magistracy to the local eruption of epidemic disease. When, in May 1603, the English heir apparent, James, saw that the weekly Bills showed the presence of plague in London, he was, as Mallin (1995, page 63) writes, caught between the now contradictory demands of “public legitimation and self-preservation,” but as weekly totals crept up he finally cancelled the coronation "owing to the growth of Plague and the fear that those coming to see our Coronation may spread it in the country.” Although the safety of the monarch is implicated in these health-reporting systems, it really does appear that the healthiness of places has a more general meaning and that it was understood as indicatedexpressed in values that described aggregates.

On the other side, the question of security was at least implicit in these early famine and epidemic measures. Foucault's argument is that the security provided by the Security State is given to the people and against outrageous misfortune. It is true that during the period of plague regulations, the Almighty was mnderstood astaken to be the author of things properly known as plague and thus state responsibility might be limited, but not all epidemic deaths were plague, some, rather, were pestilence. As one British plague sermon of 1603 explained, a plague was to be considered a "blowe or stripe [...] inflicted on mankind [...] [b]y God, although mediately by spirit, or corruption, or both” (Clapham, 1603, n.p.). Against such divine judgment, alone were 
prayer and repentance effective. But pestilence was the matter considered from a natural and not a spiritual point of view and God "hath created phisicall creatures for preventing and curing natural corruption, the materiall cause of our maladie and naturall sicknesse.” Thus after calling for prayer and fasting, "Magistrates and Ministers [were right to] have published naturall meanes in respect of naturall corruption., 3

Because there weare understood to be natural causes as well as divine, then, temporal as well as spiritual redress was necessary. In one pamphlet on famine, the first sermon was given over to calling down curses upon corn hoarders but the second was addressed to "worthy Magistrates" exhorting them to diligence in seeking out hidden supplies and thus "doe their duties though the people do causelessly curse them” (Fitz-Geffry, 1649, page 19). Another treatise on plague and famine addressed "Magistrates [... who] have the power to cause divine directions to bee put in execution,” directions that will "settle orders for succouring poore people” (Gouge, 1631, n.p.). Preaching a sermon to the British House of Commons in 1661, the year of the Restoration of Charles II, and in a summer when heavy rains appeared to have destroyed the annual harvest, Thomas Grenfield praised a loyal people and said that they deserved the attention of the government. He told the members of parliament that it was "now in your power to do them right, that have suffered wrong, and to feed and relieve these hungry ones, and the honour of the Action will be this, that thereby you will be followers of God" (Grenfield, 1661, n.p.). Notice that this was not a matter of private charity but of government obligation.

\footnotetext{
${ }^{3}$ Ironically Clapham's strong sense of predestination meant that he was heard as speaking of Plague only as a spiritual judgment with his fatalism considered disruptive to the implementation of plague regulations and, during the plague of 1603, he was imprisoned, occasioning the explanation offered in this Epistle (Walsham, 2004).
} 
The plague and famine regulations, then, to some extent engaged with population aggregates and, moreover, impliedy a claim by people for state protection against natural calamity. These are features of what Foucault described as the nexus of biopolitics and governmentality and that he suggested were largely absent from state arts of sovereignty and discipline. I want now to follow this nexus into the geopolitics of this early period and supplement Foucault's spatial perspective with a more explicit geography.

\section{Geography and Geopolitics}

While space was important in Foucault's analysis, geography unfortunately was not. By concentrating on the state, Foucault produced suggestive typologies of the apparatuses of government (dispositifs) and he illustrated these distinctions with European examples. There is an implicit transition model here with each state emphasizing law, discipline and then governmentality for more or less similar reasons, and experiencing these shifts in focus either earlier or later than other states. But there was a historical geography and a geopolitics to the elaboration of state apparatuses with both relevant for thinking about the relations between security and vitality. The historical geography of the public health innovations during the Age of Plagues is well known (Kearns, 1989). In Europe, the Black Death of 1347-53 took perhaps one-third of the population (Kelly, 2005). What is striking about the response to this catastrophe is that measures adopted by Italian states after this first epidemic were still being debated and only lately adopted by northern European cities in the late-sixteenth century.

The adoption of measures of protection in Italy was not only a model for its neighbours, first in southern and then in northern Europe, but also a protection for them, a buffer between northern Europe and the disease corridor that was the Silk 
Road. For much of the sixteenth century, Venice and other Italian ports were the interface with trade that came overland to the eastern Mediterranean and then, in the main, across the Mediterranean to the warehouses of the Italian merchants. The relations between an original plague reservoir probably in central Africa, the establishment of a reservoir among the rodents of central Asia from the fourteenth century and its periodic transmission to Europe, about once a decade from the midfourteenth to the sixteenth centuries, were shaped not only by patterns of human movement but also by political geography.

For the first European plague epidemics, the so-called Justinianie plagues of the early sixth century, Sarris (2002) suggests that the "crucial prerequisite" was the "geopolitical context” of military alliances and "close economic contact” between Ethiopia and Byzantium (Sarris, 2002,page 172). In like manner the connections between central Asia and Europe were overlain by the dynamics of several empires. In the mid-thirteenth century the Mongol Empire stretched from northern China across to eastern Europe. In parts of the Empire, nomadic ways were given up for agriculture, towns, and trade. This facilitated the communication of goods and pathogens along the so-called Silk Road. However, the new territoriality contributed to the quartering of the Empire after 1260 and of the four khanates, the two most sedentary were themselves then subject to further internal division (Morgan, 2009). From 1335 the dissolution of the Ilkhanate, centred on Persia, produced decades of warfare and conflict that not only produced more than a dozen new territories but threw armies and people across the western end of the old Mongol Empire at the very time that the plague stepped again into Europe.

The fourteenth and early-fifteenth centuries also saw the Ottoman Empire extend itself by continual warfare into the Anatolian and Balkan lands of the 
Byzantine Empire. The wars by which were yielded Serbia and Bulgaria in the fourteenth century, Bosnia, Albania, Herzegovina and Montenegro in the fifteenth, and in the sixteenth, Egypt, Syria, Palestine, Algeria, Iraq, Libya, Hungary, Georgia, Azerbaijan, and Armenia, not only themselves disrupted civil administration throughout much of the lands that were the interface between central Asia and Europe, but also installed across this vast space a cellular series of rentier regimes that never established regulatory regimes equal to those that Foucault described as supervening the waning feudal polities of western Europe. For the Ottoman Empire of the sixteenth- and seventeenth-centuries, White (2010) describes a set of plague practices that on occasion separated the sick from the healthy but did not accept the quarantine system of the Italian cities, and probably for reasons that were also geopolitical in nature for the interruption of communication within the Empire was looked upon as divisive and antisocial (Shefer-Mossensohn, 2009). Only in response to the later plagues of the eighteenth and early-nineteenth century was quarantine adopted within the realm of the Ottoman Empire (Panzac, 1985). The acceptability of quarantine within Europe may perhaps have owed something at least to the ready identification of international traders, travelers or migrants as a threat foreign and external; a further implication of the differences between the early modern systems of empires on one hand and competitive states on the other (Jones, 1981).

Rather than an autochthonous development of states, the regulation of famine and epidemics was always essentially international. Food security might even on occasion be a distinct goal of foreign policy. In a study of conflict along the mutual borders of the Russian and Ottoman empires, LeDonne (2006) suggests-proposes that the attempt to displace Ottoman control of the Black Sea required the division of Poland so that, in getting the wheatfields of the Ukraine, the Russian Empire might 
provision its army for battles against the Ottomans. Although not generally a cause of war, the international trade in corn was ever a sensitive matter in medieval and early modern times. In 1394,A royal dispensation was required in 1394 tlefte give merchants the right to freelyfree to export corn and in this case it was understoodbut as a temporary right and as excluding the export of corn to England's enemies (Gras, 1915, page 136). More generally between the thirteenth and seventeenth centuries the export of corn was only tolerated when supply was plentiful and prices low. The international dimension of the trade was evident also in the regulations concerning domestic sale. In the City of London, according tøby fourteenth-century regulations, non-citizens were not to "sell corn by sample, nor might they sell it to other strangers" (Gras 1915, page 65).

The English government sought good relations with those European merchants most dominant in the corn trade so that in bad years itthey might rely upon good will cultivated during goodbetter. In the face ofFacing dearth, the commerce in grain could be as much a matter of morality as economy. In 1389 English merchants were allowed to transgress a ban on exports since grain was so scarce in the Baltic that the great exporting centre of Danzig was pleading for supply (Gras 1915, page 116). In 1640 one Dutch trader was given an exceptional license to export English corn because, "often, in times of scarcity in England [he had] brought over hither a supply for his Majesty's subjects” (Gras, 1915, page 196, quoting the statute). In the extremity of the worst famine (1315-17) of the Middle Ages, the English king, Edward II "wrote to both the king of France and the duke of Brittany requesting that merchants of Newcastle-on-Tyne be allowed to buy grain in their lands and ship it home” (Sharp, 2012, page 12). During a famine of 1437-9, Henry VI "wrote to the Master of the Teutonic Order [which controlled some of the ports in the Baltic] with a request that 
English merchants be allowed to buy 10 to 20 shiploads of grain to meet English needs" (Sharp, 2012ibid, page 18).

Health measures too had their diplomatic side. In 1655 the government of Scotland proclaimed that it had "pleased the Lord to visit our Brethren and Neighbors of the United Provinces with the Pestilence” but "notwithstanding the said Visitation, the Trade and Commerce with those ports, and from them, is not at all lessened" so it ordered that no ship from that country would be given warrant to land "unless the Skipper bring Certificate from what place he came, specifying, whether the same were infected or not" and if that place of origin be announced as infected, then, a quarantine of forty days would intervene and if free of infection, then, twenty days (Scotland, Privy Council, 1655). These bills of health were perhaps first demanded in 1626 by the port of Marseille (Edelman, 1963). This required that the authorities of the suspect place be trusted to cooperate in issuing honest reports about the local state of health. In the eighteenth century Britain placed consuls in many foreign ports and relied only upon its own officials alone to issue bills of health to ships leaving for England (Booker, 2007). In similar fashion, in 1830, for example, Brazil informed foreign powers that "wishing to prevent $[\ldots]$ certain captains of merchant vessels belonging to foreign nations [...] not causing the manifests, passports and bills of health, to be duly certified by the Brazilian consuls, has thought fit to determine that [...] no merchant vessel shall be admitted to entry at the custom houses of this empire, unless provided with the document” (Anon, 1830, page 8).

In 1838 the sultan of the Ottomans asked Austria for assistance in establishing quarantine stations throughout the Ottoman Empire (Harrison, 2006). In 1851, and in recognition of the greater health security produced for the Mediterranean by the cooperation of the Ottoman Empire, twelve nations met in Paris to discuss 
harmonizing quarantine regulations throughout the Mediterranean. Although this first International Sanitary Conference achieved little (Harrison, 2006), it did underline the evidently international nature of sanitary regulations. Contributing to the difficulties in 1851 were arguments about the suitability of quarantine for the shock disease of the mid-nineteenth century, cholera. The British representatives insisted that cholera was not carried from place to place but was generated out of local conditions, miasmatically.

The diplomacy involved in the quarantine system is perhaps nowhere more evident than in the unraveling of the system under the pressure of the new British doctrine. In December 1881 the Egyptian International Quarantine Boards began to impose quarantine upon all ships seeking entry at the southern end of the Suez Canal (Watts, 2006). There were reports of cholera from this port of Aden and yet, instructed to act on the principle that cholera was not contagious, the British Political Resident at Aden gave clean bills of health to all ships regardless of the presence aboard of cases of cholera, or of cholera reported from Bombay, the principal originating port for the ships. At Bombay itself, no steps were taken to investigate ships since the British saw cholera as endemic to the region and tied to its environment. The British port medical officer of Bombay did not even have a boat suitable for visiting and inspecting ships leaving the city (Watts, 2006). Seeking to set quarantine aside, the British officials affected horror that their bills of health were not accepted by the Ottoman officials and in 1882 occupied Egypt to allowso that ships to passcould go directly from India through the Suez Canal, uninterrupted by quarantine of any kind.

The elaboration of health and famine policies during the periods of sovereignty and discipline, then, need to be mnderstood-viewed within the framework 
of a system of states and not as directed by the evolution of state forms in isolation.

Much the same is true of our current moment so that, rather than the Security State, we must attend to a system of states in a network, overdetermined, as I will argue, by the recurring negotiation of the inequalities of global capitalism. The state practices that are generally associated with the field of security continue to prioritize those aspects of territoriality and discipline that Foucault identified as part of the sovereign and the regulatory state and that, paradoxically, he saw as marginalized by the biopolitics and governmentality of what he called the Security State.

\section{The Geopolitics of Life}

Taking up Dean’s (1994) characterization of Foucault’s work as developing critical and effective histories, we might look backwards through the telescope and ask if the distinction between safety and security suggests productive strategies for engaging the causes of present discontents. Foucault sketched a transition from a world of safety to a world of security as "plague, death, and war" were eclipsed by a new set of anxieties about “everyday dangers” (Foucault, 2008, page 66). For Foucault, this is the form of security with which the Security State concerns itself. There was an interesting continuity in Foucault's thought in this area. His experience of living in Sweden in 1955-8, gave Foucault "a grim vision of a future in which, in 50 or 100 years time, everyone would be 'happy, rich and ascepticized'” and "he never displayed any great affection for the country, which he regarded as too 'medicalized'” (Macey, 2004, page 50). The same theme is evident in Foucault's (2008, page 66) description of liberalism as a system where "individuals or the community have the least exposure to danger.” Featuring prominently in the lecture series, The Birth of Biopolitics, this version of liberalism was, claims Senellart (2008, page 329), the focus of Foucault's "sole incursion into the field of contemporary history throughout 
his teaching.” Foucault's argument was that the counterpart to economic risk-taking in a free market economy was liberalism’s “famous disciplinary techniques for taking charge of the behavior of individuals” (Foucault, 2008, page 67). In this sense, liberal governmentality promotes freedom but only at the expense of "liberogenic" regulation (ibid, page 69). For Foucault, this was how a "crisis of the apparatus of governmentality” was “currently experienced, lived, practiced, and formulated” (ibid, page 70).

The political issue that is highlighted by these formulations is the question of personal liberty, the sense of living in a time when there is a permanent crisis under the sign of the claim that there is already too much government while there is also deepening regulation, protecting people against proliferating danger. Certainly some people, and Foucault (2008, page 75) cited a conservative art critic, Bernard Berenson, affected to fear the interventionist state more than they feared nuclear war, but even for the 1970s, it seems limited to argue that security was primarily an issue that arose as part offrom state regulation of individual behaviour.

While "state-phobia" (Foucault, 2008, page 76) is an interesting matter, the threat of nuclear war and the structural violence of poverty seem more urgent causes of vital insecurity, and each was mnderstood-seen as a security issue at the time and they profoundly shaped systems of government in, respectively, rich and poor countries. Food security was conceptualized in terms of national self-sufficiency in poor countries (Biswas and Biswas, 1975) and for many rich countries nuclear strategy was understood as a problem of ensuring national safety in face of nuclear proliferation (Wilcox, 1972). The distribution of well-being in India after independence (1947) was profoundly shaped, in the first place, by a system of land reform (Besley and Burgess, 2000) and then by the so-called Green Revolution 
(Frankel, 1971). The first saw some redistribution of land towards the rural poor yet without increasingdid not raise more food supply for the cities, while the second produced higher food transfers out of rural India but concentrated agrarian land ownership once again. These profound shifts in the economic rights of the majority of the Indian population were each justified as part of a search for food self-sufficiency. In the United States, the imperatives of a Nuclear Security State were claimed in support of the most extreme extension of presidential powers in the 1950s and 1960s (Wills, 2010) while in foreign policy the threat of a nuclear Soviet regime was offered as the reason why liberation movements that might be sympathetic to communism were intolerable in third world countries (Kauzlarich and Kramer, 1998). For India, rural folk eating the food they grew rather than sending it to the market, and for the United States, an existential threat posed by a nuclear Soviet Union, were each seen as matters of vital security that dictated important aspects of governance. In other words, there does seem to be continuity from an early-modern problematic of government that engaged the apocalypse of war, disease, and famine.

In one sense, Foucault acknowledged this in The Birth of Biopoltiics but in a way that severed the connection between territoriality and sovereignty on one side, and vitality on the other. Foucault (2008, page 6) suggested that modern European sates were created when the "horizon" of government shifted from the ambition of "total and global empire" to the cultivation and defence of a national realm. The mutual destructionappalling mortality of the Thirty Years War encouraged the mutual recognition of limited interference in the affairs of other states with the Treaty of Westphalia (1648) and a focus upon balancing powers in Europe, "the calculation of European equilibrium” (ibid, page 60), through adjusting frontiers to prevent the emergence of a hegemon that was yet Metternich's ambition at the Congress of 
Vienna in 1815. It was also in the context of the European balance of powers that Foucault offered one of his few discussions of colonialism. The novel contribution of Britain during the nineteenth century was, according to Foucault, that it sought to balance the parallelogram of European forces by acting as "economic mediator between Europe and the world market” (ibid, page 60). The zero-sum game of the European mercantilist imaginary was now stuspended in favouret aside for ef an expansionary vision of a growing global market.

With this new period of the Security State, then, Foucault comprehended the regulation of vitality within states as the choreography of individual behaviors, elevating and managing everyday dangers. The relations between states were now about minimizing the risk of all-out war within Europe and this effort involved forming European states that could balance against the risk of Empire, and that could grow in force through colonial rather than European appropriations. Yet the horsemen

of the Apocalypse are with us yet and they are felt to impose imperatives upon states in ways that even todaycontinue to direct the priorities of government, and these imperatives continually turn geopolitical. Empire weaves together biopolitics and geopolitics, with respect both to the HIV/AIDS pandemic (Elbe, 2005; Ingram, 2007) and to the so-called Global War on Terror (Butler, 2004; Kearns, 2013).

\section{Political Economy and Empire}

Colvin (2011) states a truth universally acknowledged: "HIV/AIDS has always been one of the most thoroughly global of diseases.” AIDS was first reported in 1981 (Centers for Disease Control, 1981), an international definition was adopted in 1986 (World Health Organization, 1986), and within a decade of the first reports, 163 countries had reported cases of AIDS (Mann, 1992). This is a pandemic of connectedness, for some "the first epidemic of globalization" (Barnett and Whiteside 
2002, page 2). The United States shows in microcosm a rather general feature of the epidemic. Within a few years, the geography of the disease reflected the connectedness of places rather than the route taken by the epidemic (Gould 1993). The intense interconnectedness of the world means that, even in the case of a disease spread largely by the most intimate of behaviours, the isolation required for effective quarantine is an option for only a handful of places. The disease is both symptom and consequence of circulation, and policies to address it must recognize this global interdependence. In 1999 the US Ambassador to the United Nations, the late Richard Holbrooke, pressed the UN Security Council to recognize AIDS as a threat to international security, a theme repeated in 2000 by Al Gore in a speech to the Council (Prins, 2004; Elbe, 2006). 


\begin{tabular}{|l|r|r|r|r|c|}
\hline & $\begin{array}{r}\text { Population } \\
\text { (millions) }\end{array}$ & $\begin{array}{c}\text { People } \\
\text { living with } \\
\text { HIV } \\
\text { (millions) }\end{array}$ & $\begin{array}{c}\text { \% Needing ART } \\
\text { who receive it at } \\
\text { public expense }\end{array}$ & $\begin{array}{c}\text { \% Needing ART } \\
\text { who receive it at } \\
\text { international } \\
\text { expense }\end{array}$ & $\begin{array}{c}\text { \% HIV infected } \\
\text { people receiving } \\
\text { ART at public } \\
\text { expense }\end{array}$ \\
\hline $\begin{array}{l}\text { South } \\
\text { Africa }\end{array}$ & 51.8 & 5.60 & 58.0 & 8.0 & 26.9 \\
\hline Nigeria & 170.9 & 3.40 & 7.8 & 23.2 & 3.2 \\
\hline India & 1210.2 & 2.39 & 7.1 & 35.9 & 3.7 \\
\hline Brazil & 194.0 & 0.49 & 77.1 & 0.9 & 47.2 \\
\hline Thailand & 65.9 & 0.49 & 60.5 & 10.5 & 39.5 \\
\hline Haiti & 10.4 & 0.12 & 0.5 & 57.5 & 0.3 \\
\hline
\end{tabular}

Table 1. HIV and ART treatment, $2011^{4}$

With treatment, many AIDS deaths may be averted. For 2011, UNAIDS

(2012) estimated that there were 34 million people infected with HIV, with 2.5

million new infections that year. It estimated also that there were 14.8 million with

CD4 counts below 350, and thus in need of Anti-Retroviral Therapy (ART), without

which they might expect to die within two years. ${ }^{5}$ Of these, 8 million were currently

receiving it. Table 1 shows the dimensions of the issue for a few countries. Of these

\footnotetext{
${ }^{4}$ Data from UNAIDS, http://www.unaids.org/en/dataanalysis/, supplemented with material from Center for Disease Control and Prevention, http://www.cdc.gov/globalaids/Global-HIV-AIDS-at-CDC/countries/

${ }^{5}$ There is now a strong recommendation that ART treatment be started when CD4 counts drop below 500, which would expand the numbers requiring treatment: Panel on Antiretroviral Guidelines for Adults and Adolescents (2013) Guidelines for the use of antiretroviral agents in HIV-1-infected adults and adolescents (Department of Health and Human Services, Washington DC). Available at http://aidsinfo.nih.gov/ContentFiles/AdultandAdolescentGL.pdf
} 
countries, Nigeria currently treats but $31 \%$ of those estimated to be in need of ART whereas in Brazil 78\% of those in need of it are given ART. Some countries, such as Haiti, are very heavily dependent upon international aid for the treatment they offer. Needs are certain to grow since all those people currently HIV positive will see their CD4 counts fall, unless death supervene from another cause. Were they to need to treat with ART all those currently HIV positive, the increase in spending would be significant, for Haiti ruinous since at present only $0.3 \%$ of those infected with HIV are treated with ART at public expense. In this context, Jøão-Biehl (2004, page 107) reports on the Brazilian case as a transition from "political to biological rights.” In Brazil, the incidence of HIV is about one person in 400 whereas in South Africa it is one in nine and South Africa is a country with a right to health enshrined in the constitution (Hogerzeil et al, 2006) so that when we speak of therapeutic citizenship (Nguyen, 2005, 2010) in the context of ART therapies, we are implying a very different reorientation of the political economy of the state in the case of South Africa than for Brazil.

There are currently nine countries where more than $10 \%$ of those in the principal working ages (15-49) are living with HIV/AIDS (Central Intelligence Agency, 2013). Thus, in Swaziland, Botswana, Lesotho, South Africa, Zimbabwe, Zambia, Namibia, Mozambique, and Malawi, at the very least, an economically significant part of the workforce can only remain active if ART therapy is available. The management of the economy, then, rests upon organizing a therapeutic citizenship. In a dangerous way, the workforce is rented from a combination of international aid and the global pharmaceutical industry. In these countries, life and economy are at the mercy of international agreements around the pricing of medicines (Flynn, 2011; Grover et al, 2012) and the provision of aid (Masellis and Gunn, 2002). 
Therapeutic citizenship, then, a set of rights that confer life, is only to be realized within an international context.

As Đavid-Nally has demonstrated (2011), the same argument is readily made for the biopolitics of food security; the right to life is conditional upon the relations of international political economy with its defence of property rights that extract rent for subsistence at molecular and territorial scales. Nally also draws attention to an aspect of Foucault's biopolitical argument that is helpful for understanding the form of governance that regulates life in this area but which needs to be considered outside the dialectic of liberogenic processes and state-phobic attitudes if we are to develop it in ways that are politically useful for addressing present discontents. Foucault (1978) contrasted the classical age, where the sovereign could defend itself by taking the life of subjects, a "right to take life or let live” (page 136), with a modern governmentality in which there is "a power to foster life or disallow it to the point of death" (page 138). This murderous power is no longer exercised "in the name of a sovereign who must be defended" but, rather, "on behalf of the existence of everyone” (ibid, page 137). Taking the side of an aggregate population, "genocide is indeed the dream of modern powers" (ibid, page 137). Foucault suggested two ways that the dispensability of lives to save life might be legitimated using population arguments. In the first, a "people" is expelled from the "population" because it is understood held to have cast itself adrift by failing to anchor itself properly through property relations, failing to abide by the disciplines of the market, "try[ing] to elude the apparatus by which the population exists, is preserved, subsists, and subsists at an optimal level” (Foucault, 2007, page 44). The second technique retains the inadequates within the population but treats them as sub-norm, below average and thus justifying intervention "to bring the unfavorable in line with the more favorable" (ibid, page 63). 
Yet, the reference to sub-norms and to a people outside a population, does not seem adequate to the sheer violence of disallowing life to the point of death, or of dreaming genocide as a form of governance. Because they take liberty and the subjectivaiton of individuals as their primary focus, the lectures on the Security State in Security, Territory, Population and in The Birth of Biopolitics rarely touch the theme of collective violence that is so prominent in the earlier first volume of the History of Sexuality. From this earlier treatment, Judith-Butler (2004) has developed her own politically salient reading of the Global War on Terror as resting upon the hegemon denying for itself, but visiting upon its victims an intense "precarity" of life. A division is made between lives that count and those deaths that do not even need to be counted (Butler 2009). Making this division rests upon abrogating extraordinary powers to the executive. These powers are not so much liberogenic as anti-liberal and they are justified with respect to notions of security that are certainly not about the dangers of the everyday. Naomi-Klein (2007) notes that it is precisely the exceptional nature of the projected crises that allows the adoption of such "shock" measures.

There are three principal contexts in which this callous disqualification of lives occurs: state bankruptcy, war, and colonialism. Each of these has a necessarily geopolitical dimension. National bankruptcy is always imposed from outside at the behest of foreign investors, states, or banks, who seek extraordinary measures to realize assets in repayment of toxic debt. These extraordinary measures produce patterns of exclusion and desperation that deny subsistence to many and fuel divisions that often have murderous consequence, as Uvin (1998) shows for Rwanda.

With the end of the Cold War, the executive presumption based on nuclear fears required recasting, and thus in this 'unipolar moment' (Krauthammer, 1990) the US presidency crafted a new set of security priorities that equally required lack of 
accountability at home and projected unbridled force abroad. This seeming contempt for people living in other countries raises questions about the international relations between states, life and law. To render this geopolitics more evident, ift may beis helpful to think of the Global War on Terror as an exercise in what Giorgio Agamben terms the exception (Gregory, 2004). In one interview of 2004 (Sacco, 2004), Agamben identified his account of the exception as using the 'same genealogical and paradigmatic method practiced by Foucault' but noting two lacunae in Foucault, 'law and theology. It seemed natural for me to address my two latest studies in this direction' (quoted in Snoek 2010, page 46). ${ }^{6}$ For Agamben, at its limit, sSovereignty is exercised without the normal legal forms, which are suspended. $\underline{\text { Agamben was }}$ talking about state sovereignty but the argument is also suggestive if given a colonial reading. Because, in declaring a Global War on Terror, the US presumes to suspend international law and agreements in pursuit of terrorists, we might I think claim that this is therecognise here a form of imperial sovereignty, the right to assert the global exception (Kearns, 2009). The same suspension is part of the emergency powers that seem to be the normal form of colonial rule (Hussain, 2003; Kearns, 2006b). These geographies of exception suspend the protections for life, asserted in international agreements on human rights or in the formal structures of liberal governance, colonial or not. The forms in which security implicates life, and the vital geographies stalked by the horsemen of the Apocalypse are ever resolutely geopolitical.

\footnotetext{
${ }^{6}$ The two works Agamben was referring to have been published in English as The Time that Remains (2005a) and State of Exception (2005b). The first takes up Theology and the second, Law.
} 


\section{References}

Agamben G, 2005a The Time that Remains: A Commentary on the Letter to the

Romans trans. P Dailey (Stanford University Press, Stanford CA); first published in

$\underline{\text { Italian } 2000}$

Agamben G, 2005b State of Exception trans. K Attell (Chicago University Press,

Chicago IL); first published in Italian 2003

Anon, 1665 Orders conceived and published by the Lord Mayor and the Aldermen of the city of London, concerning the Infection of the Plague (City of London, London) Anon, 1830 “Brazilian spoliations” Niles’ Weekly Register 38 8-9

Barnett T, Whiteside A W, 2002 AIDS in the Twenty-First Century: Disease and

Globalization (Palgrave Macmillan, Basingstoke UK)

Bashford A, 2006 "Global biopolitics and the history of world health" History of the Human Sciences 19(1) 67-88

Basing P, Rhodes D E, 1997 “English plague regulations and Italian models: Printed and manuscript items in the Yelverton collection” British Library Journal 23 60-67

Besley T, Burgess R, 2000 “Land reform, poverty reduction, and growth: Evidence from India” Quarterly Journal of Economics 115(2) 389-430

Biehl J, 2004 “The Activist State: Global pharmaceuticals, AIDS, and citizenship” Social Text 22(3) 105-132

Biswas M R, Biswas A K, 1975 “World Food Conference: A perspective” Agriculture and Environment 2(1) 15-37

Booker J, 2007 Maritime Quarantine: The British Experience, c.1650-1900 (Ashgate, Aldershot UK)

Field Code Changed 
Boyle C, 2006 "The mystery of modern wealth: Mercantilism, value, and the social foundations of liberal international order” European Journal of International

Relations 14(3) 405-429

Brown T, 2011 “'Vulnerability is universal': Considering the place of 'security' and ‘vulnerability’ within contemporary global health discourse” Social Science \& Medicine 72(3) 319-326

Butler J, 2004 Precarious Life: The Powers of Mourning and Violence (Verso, London)

Butler J, 2009 Frames of War: When is Life Grievable? (Verso, London)

Centers for Disease Control, 1981 “Pneumocystis Pneumonia-Los Angeles”

Morbidity and Mortality Weekly Report 30(21) 250-252

Central Intelligence Agency, 2013 World Factbook. Country comparison: HIV/AIDS, Adult Prevalence, https://www.cia.gov/library/publications/the-worldfactbook/rankorder/2155rank.html

Cipolla C M, 1978 “The ‘Bills of Mortality’ of Florence” Population Studies 32(3) $543-548$

Clapham H, 1603, An Epistle Discoursing upon the Present Pestilence (Widow Newberry, London, 1603)

Colvin C J, 2011 "HIV/AIDS, chronic diseases and globalization” Globalization and Health 7(31) doi:10.1186/1744-8603-7-31

Cook A P, Cook D N, 2009 The Plague Files: Crisis Management in SixteenthCentury Seville (Lousiana State University Press, Baton Rouge LA)

Dean M, 1994 Critical and Effective Histories: Foucault's Methods and Historical Sociology (Routledge, London) 
Dillon M, Lobo-Guerrero L, 2008 "Biopolitics of security in the 21st century: An introduction” Review of International Studies 34(2) 265-292

Edelman S, 1963 “International travel and our national quarantine system” Temple Law Quarterly 37 28-40

Elbe S, 2005 “AIDS, security, biopolitics” International Relations 19(4) 403-419 Elbe S, 2006 "Should HIV/AIDS be securitized? The ethical dilemmas of linking HIV/AIDS and security” International Studies Quarterly 50(1) 119-144

Elden S, 2007 “Government, calculation, territory” Environment and Planning D. Society and Space 25 562-580

Fitz-Geffry C, 1648 Gods Blessing upon the Providers of Corne: and Gods curse upon the hoarders (M.S., London)

Flynn M, 2011 “Corporate power and state resistance: Brazil’s use of TRIPS flexibilities for its National AIDS Program”, in Intellectual Property, Pharmaceuticals and Public Health: Access to Drugs in Developing Countries Eds K C Shadlen, S Guennif, A Guzmán, N Lalitha (Edward Elgar, London) 149-177 Foucault M, 1978 The History of Sexuality. Volume 1: An Introduction trans. R Hurley (Pantheon Books, New York); first published in French 1976 Foucault M, 2007 Security, territory, population: Lectures at the Collège de France, 1977-1978 Ed. M Senellart, trans. G Burchell (Picador, New York); first published in French 2004

Foucault M, 2008 The Birth of Biopolitics: Lectures at the Collège de France, 19781979 Ed. M Senellart, trans. G Burchell (Picador, New York); first published in French 2004

Frankel F R, 1971 India's Green Revolution: Economic Gains and Political Costs (Princeton University Press, Princeton NJ) 
Gouge W, 1631 Gods Three Arrowes Plague, Famine Sword, in Three Treatises

(Edward Brewster, London)

Gould P, 1993 The Slow Plague: A Geography of the AIDS Pandemic (Blackwell, Oxford UK)

Gras N S B, 1915 The Evolution of the English Corn Market from the Twelfth to the Eighteenth Century (Harvard University Press, Cambridge MA)

Gregory D, 2004 The Colonial Present: Afghanistan, Palestine, Iraq (Blackwell, Oxford UK)

Grenfield T, 1661 The Fast: As it was Delivered in a Sermon at St. Margarets in Westminster to the Honorable House of Commons upon Wednesday the 12th. of June 1661 (Henry Brome, London)

Grover A, Citro B, Mihir M, Lander F, 2012 "Pharmaceutical companies and global lack of access to medicines: Strengthening accountability under the right to health” Journal of Law, Medicine \& Ethics 40(2) 234-250

Harrison M, 2006 “Disease, diplomacy and international commerce: The origins of international sanitary regulation in the nineteenth century” Journal of Global History 1(2) $197-217$

Herbruck W, 1929 “Forestalling, regrating and engrossing” Michigan Law Review 27(4) 365-388

Hogerzeil H V, Samson, M, Casanovas J V, Rahmani-Ocara L, 2006 “Is access to essential medicines as part of the fulfilment of the right to health enforceable through the courts?” Lancet 368 305-311

Horrox R, 1994 The Black Death (Manchester University Press, Manchester UK)

Hussian N, 2003 The Jurisprudence of Emergency: Colonialism and the Rule of Law (University of Michigan Press, Ann Arbor MI) 
Ingram A, 2007 "HIV/AIDS, security and the geopolitics of US-Nigerian relations"

\section{$\underline{\text { Review of International Political Economy 14(3) 510-534 }}$}

Jones E, 1981 The European Miracle: Environments, Economies and Geopolitics in the History of Europe and Asia (Cambridge University Press, Cambridge UK)

Kauzlarich D, Kramer R C, 1998 Crimes of the American Nuclear State: At Home and Abroad (Northeastern University Press, Boston MA)

Kearns G, 1989 “Zivilis and Hygaeia: Urban public health during the epidemiologic transition”, in The Rise and Fall of Great Cities Ed. R Lawton (Belhaven, London) pp $96-124$

Kearns G, 2006a “The social shell” Historical Geography 34 49-70

Kearns G, 2006b "Bare life, political violence and the territorial structure of Britain and Ireland”, in Violent Geographies: Fear, Terror and Political Violence Eds D Gregory, A Pred (Routledge, New York) pp 9-34

Kearns G, 2007 “The history of medical geography after Foucault”, in Space, Knowledge and Power: Foucault and Geography Eds S Elden, J Crampton (Ashgate, Aldershot UK) pp 205-222

Kearns G, 2009 Geopolitics and Empire: The Legacy of Halford Mackinder (Oxford University Press, Oxford UK)

Kearns G, 2013 "The Butler affair and the geopolitics of identity" Environment and Planning D: Society and Space 31(2) 191-207

Kearns G, Reid-Henry S, 2009 “Vital geographies: Life, luck and the human condition” Annals of the Association of American Geographers 99(3) 554-574

Kelly J, 2006 The Great Mortality: An Intimate History of the Black Death, the Most Devastating Plague of All Time (HarperCollins, New York) 
Klein N, 2007 The Shock Doctrine: The Rise of Disaster Capitalism (Allen Lane, 2007)

Krauthammer C, 1990 "The unipolar moment” Foreign Affairs 70(1) 23-33

LeDonne J P, 2006 “Geopolitics, logistics, and grain: Russia’s ambitions in the Black Sea Basin, 1737-1834” International History Review 28(1) 1-41

Legg S, 2005 “Foucault’s Population Geographies: Classifications, biopolitics and governmental spaces” Population, Space and Place 11(3) 137-156

Legg S, 2011 "Security, territory and colonial populations: Town and empire in Foucault's 1978 lecture course”, in Postcolonial Spaces: The Politics of Place in Contemporary Culture Eds A Teverson, S Upstone (Palgrave Macmillan, Basingstoke UK) pp 146-163

Macey D, 2004 Michel Foucault (Reaktion Books, London)

Mallin E S, 1995 Inscribing the Time: Shakespeare and the End of Elizabethan

England (University of California Press, Berkeley CA)

Mann J M, 1992 “AIDS-The second decade: A global perspective” Journal of Infectious Diseases 165(2) 245-250

Masellis M, Gunn S W A, 2002 "Humanitarian medicine: A vision and action” Journal of Humanitarian Medicine 2 33-39

Morgan D, 2009 “The decline and fall of the Mongol Empire” Journal of the Royal Asiatic Society 19(4) 427-437

Nally D, 2011 “The biopolitics of food provisioning” Transactions of the Institute of British Geographers 36 37-53

Newman K, 2012 “Bubonic plague and quarantine in early modern England” Journal of Social History 45(3) 809-834 
Nguyen $V_{-}-\mathrm{K}, 2005$ “Antiretroviral globalism, biopolitics, and therapeutic citizenship” in Global Assemblages: Technology, Politics, and Ethics as Anthropological Problems Eds A Ong, S J Collier (Blackwell, Oxford UK) pp 124144

Nguyen V-K, 2010 The Republic Theraphy: Triage and Sovereignty in West Africa's Time of AIDS (Duke University Press, Durham NC)

Nielsen R, 1997 “Storage and English government intervention in early modern grain markets” Journal of Economic History 57(1) 1-33

Panzac D, 1985 La peste dans l'empire ottoman, 1700-1850 (Éditions Peeters, Louvain)

Prins G, 2004 “AIDS and global security” International Affairs 80(5) 931-952

Quack S, 2007 “Legal professionals and transnational law-making: A case of distributed agency” Organization 14 643-666

Sacco G, 2004 "Intervista a Giorgio Agamben: dalla teologia politica alla teologia economica" Rivista della Scuola superiore dell'economia e delle finanze 1(1), http://rivista.ssef.it/site.php?page=20040308184630627\&edition=2004-04-01 Sarris P, 2002 “The Justinianic plague: Origins and effects” Continuity and Change 17(2) 169-182

Schefer-Mossensohn M, 2009 Ottoman Medicine: Healing and Medical Institutions, 1500-1700 (State University of New York Press, Binghampton NY) Scotland, Privy Council, 1655 By his Highness Councill in Scotland, for the Government thereof. It Having Pleased the Lord to Visit our Brethren and Neighbors of the United Providences with the Pestilence (Privy Council, Edinburgh) 
Senellart M, 2008 "Course context” in The Birth of Biopolitics: Lectures at the Collège de France, 1978-1979 M Foucault, trans. G Burchell (Picador, New York); first published in French 2004, pp 327-331

Shammas C, 1983 "Food expenditures and economic well-being in early modern

England” Journal of Economic History 43(1) 89-100

Sharp B, 2012 "Royal paternalism and the moral economy in the reign of Edward II: The response to the Great Famine” Economic History Review (early view) DOI: 10.1111/j.1468-0289.2012.00667.x

Slack P, 1988 "Responses to plague in early modern Europe: The implications of public health” Social Research 55(3) 433-453

Snoek A, 2010 “Agamben’s Foucault: An overview” Foucault Studies 10 44-67

Thompson E P, 1971 "The moral economy of the English crowd in the eighteenth century” Past and Present 50 76-136

Tilly L A, 1983 “Food entitlement, famine, and conflict” Journal of Interdisciplinary History 14(2) 333-349

UNAIDS (2012) UNAIDS. World AIDS Day Report 2012 (UNAIDS, Geneva Switzerland)

Uvin P, 1998 Aiding Violence: The Development Enterprise in Rwanda (Kumarian Press, Westford CT)

Walsham A, 2004 “Clapham, Henoch (fl. 1585-1614)” Oxford Dictionary of National Biography Eds H C G Matthew, B Harrison (Oxford University Press, Oxford UK), http://www.oxforddnb.com/view/article/5431

Walter J, Schofield R, Eds, 1989 Famine, Disease, and the Social Order in Early Modern Society (Cambridge University Press, Cambridge UK) 
Watts S, 2006 "Cholera and the maritime environment of Great Britain, India and the Suez Canal: 1866-1883” International Journal of Environmental Studies 63(1) 19-38

White S, 2010 "Rethinking disease in Ottoman history” International Journal of Middle East Studies 42 549-567

Wilcox W, 1972 "Japanese and Indian national security strategies in the Asia of the 1970s: The prospect for nuclear proliferation” Adelphi Papers 12(92) 30-39

Wills G, 2010 Bomb Power: The Modern Presidency and the National Security State (Penguin Press, New York)

World Health Organization, 1986 “Acquired immunodeficiency syndrome (AIDS)” Weekly Epidemiological Record 61(10) 69-75 